\title{
A Large Inguinal Angiofibroma: A Rare Entity
}

\section{Devendra K. Prajapati *1, Kapil Rampal ${ }^{1}$, Jyoti M Prajapati 2.}

${ }^{*}$ Senior Resident Department of Surgery, Deendayal Upadhyay Hospital, New Delhi, India.

2 Scholar in Computer Application.

\section{ABSTRACT}

Angiofibroma of the groin is a rare soft tissue benign tumour. Here we emphasize upon its diagnosis and management with a follow up in post-operative period. M icroscopic demonstration of well circumscribed spindle cells and hyalinised vessels along with immunohistochemistry helps in clinching a diagnosis.

KEY WORDS: Angiofibroma, Inguinal Swellings, Soft Tissue Tumours, Immunohistochemistry.

Address for correspondence: Dr. Devendra K Prajapati, WZ 423 A Nanakpura Harinagar, New Delhi-110064, India. E-Mail: dr.dev1982@gmail.com

\begin{tabular}{|l|ll|}
\hline \multicolumn{3}{|c|}{ Online Access and Article Informtaion } \\
\hline Quick Response code & International Journal of Integrative Medical Sciences \\
& \multicolumn{3}{|c|}{ www.imedsciences.com } \\
\hline $\begin{array}{l}\text { Dol: } 10.16965 / \text { ijims.2016.128 } \\
\text { Source of Funding: Self }\end{array}$ & Reviewed: 07-06-2016 & Accepted: 20-06-2016 \\
\hline
\end{tabular}

\section{INTRODUCTION}

Nucci et al. in 1997 first mentioned about cellular angiofibroma as a rare benign soft tissue tumor [1]. This soft tissue tumor usually found in the distal genital tract of either sex like: inguino-scrotal area in male and vulvo-vaginal region in females [1,2], this tumor has no morphological differences in either gender according WHO classification [3].

Grossly these tumors are well circumscribed, reside in the superficial soft tissue and contain: spindle cells and small to medium-sized vessels with mural hyalinization [4].

\section{CASE REPORT}

A 65 year female attended surgery OPD with complains of painless, gradually progressive swelling over the right groin area for one year. It was gradually increased in size and attained present size after a year. No history of fever, pain, weight loss or other sign of chronic illness.
Fig. 1: Showing deep extension of swelling.

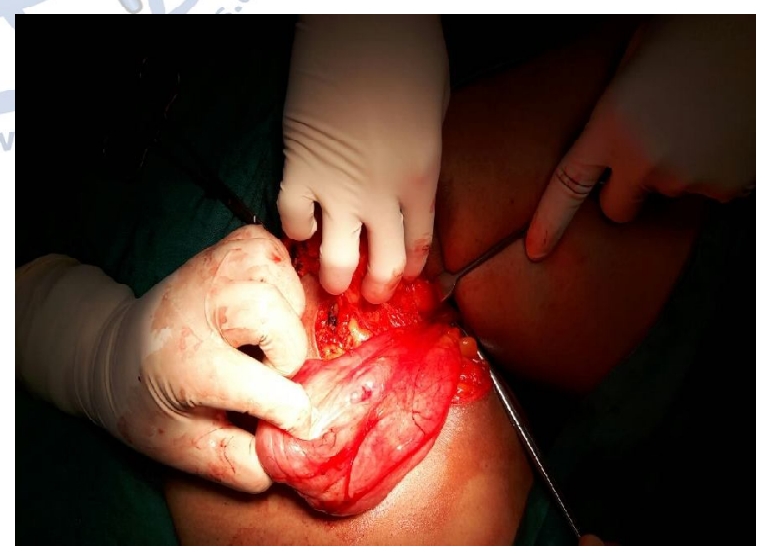

On clinical examination- patient's general condition was good. There was no pallor, icterus, cyanosis, clubbing, or generalised lymphadenopathy.

All systems were WNL.

Local examination- $22 \mathrm{~cm} \times 8 \mathrm{~cm}$ sized well defined spherical right inguinal swelling, with a smooth surface. There were no signs suggestive of inflammation. Cough impulse absent, the swelling was non-reducible and non-compressible. 
Overlying skin had no scar or dilated veins.

All routine investigations performed which were perfectly in normal range.

Radiologically- USG with color Doppler suggested a well-defined heterogenous hypoechoic space occupying lesion in right thigh and groin region in the subcutaneous plane, which showed vascular arterial and venous components suggestive of arteriovenous malformation.

CT angiography right lower limb showed a large enhancing mass lesion in the subcutaneous plane in right upper thigh inguinal region. No underlying muscle invasion and major arterial supply or venous drainage were seen.

FNAC suggestive of blood mixed aspirate showing some fibrous stromal fragments, some mixoid appearing matrix with embedded spindle cells. Suggestive of ?? Hamartoma, Firm myxoid tumor.

Finally, patient planned for excision and biopsy and under anaesthesia complete excision of swelling with capsule done. Swelling was found to be confined to the subcutaneous plane with tail extending into deep plane and simulating a hernia. Primary closure of wound was followed by an uneventful postoperative period. Suture removed on day eighth post-operative day in OPD. Intra operative findings are depicted in Figures 1 to 5.

After a great deal of dilemma, the lesion finally labelled as an "angiofibroma" on the basis histopathological report Fig 6, 7.

Report shows well defined spindle cell tumor with uniform stromal cells and hyalinised vessels.

Fig. 2: Showing subcutaneus location swelling.

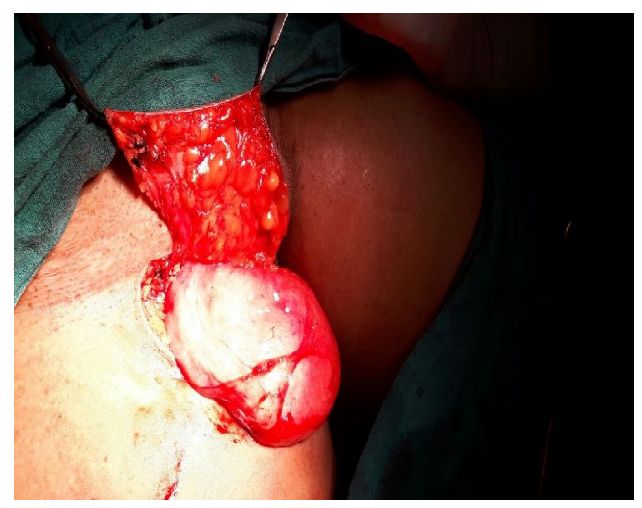

Int J Intg M ed Sci 2016;3(7):328-31. ISSN 2394 - 4137
The patient on his six monthly follow up was found to be doing good with no loco-regional recurrence of swelling.

Fig. 3: Showing deep extension.

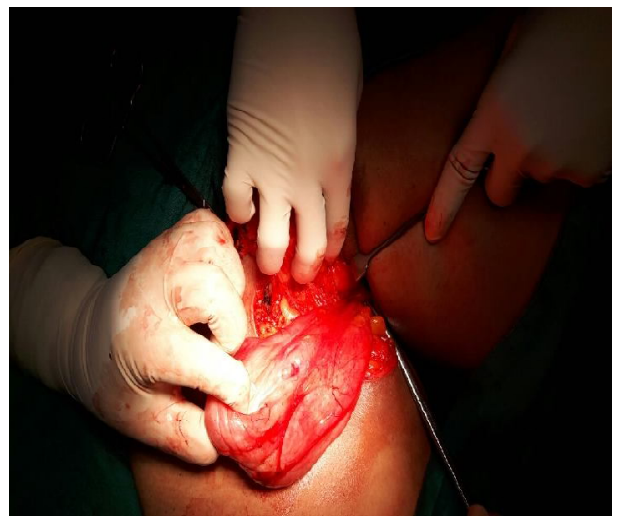

Fig. 4: Showing excised out lesion.

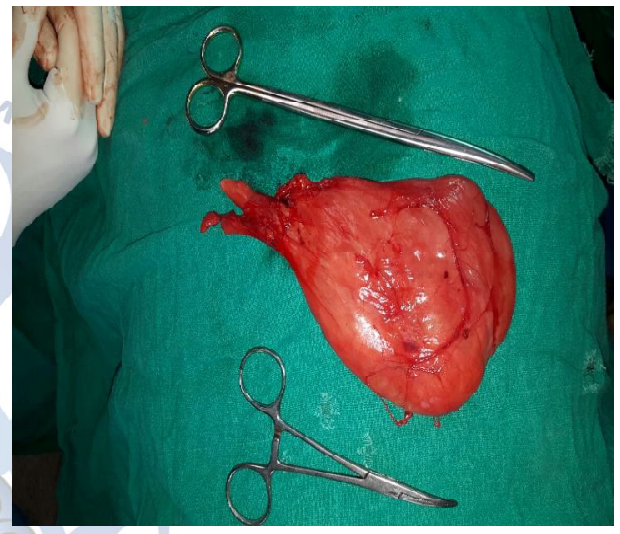

Fig. 5: Showing wound after excision.

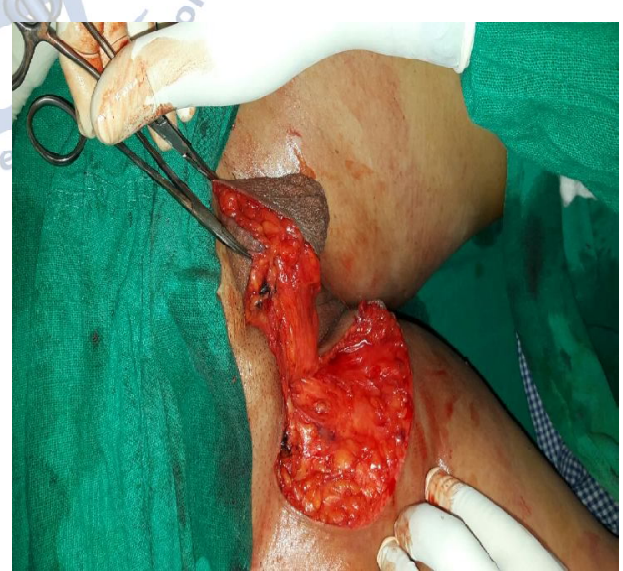

Fig. 6: Showing hylinizton of vessels spindle cells.

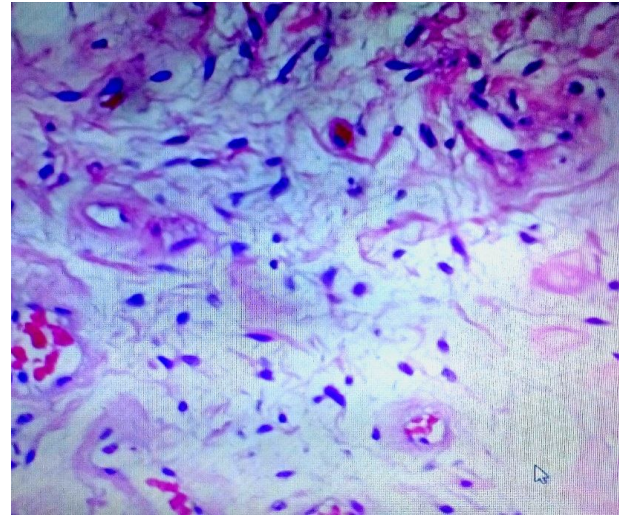


Fig. 7: Showing stromal cells and hyalinization of vessels.

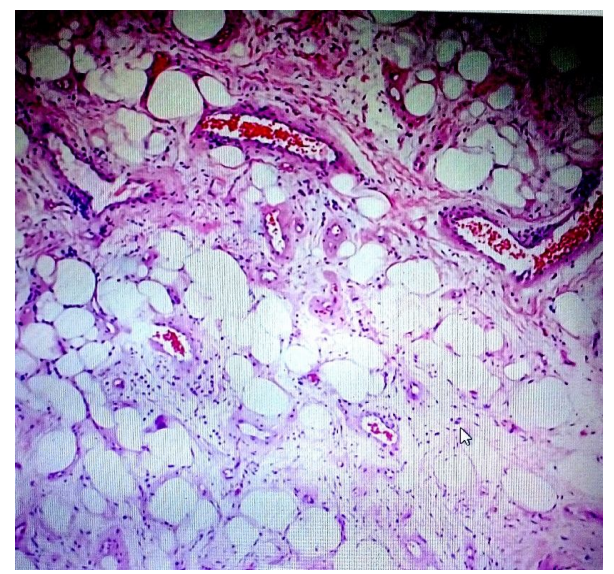

\section{DISCUSSION}

Cellular angiofibroma is a rare soft tissue tumor with equal prevalence in both genders, but a more preponderance is seen towards fifth decade of females and seventh decade of males [5].

Commonest site for cellular angiofibroma is subcutaneous tissue of the vulva in women and in inguinal and scrotal regions of men [6]. However,some angiofibromas also reported in subcutaneous tissue chest wall, retroperitoneum and the oral cavity [6-8].

Microscopically, cellular angiofibroma is a well circumscribed spindle cell tumor consisting of uniform stromal cells and hyalinised vessels, therefore the name angiofibroma was suggested on the basis of predominant blood vessels and the uniform stromal cells [1].

Cellular angiofibroma sometimes may associated with cellular atypia or sarcomatous transformation morphology [9]. These cases only require local excision with clear margins and long-term follow-up [5,6].

Angiofibroma is well encapsulated and hypervascular tumor where surgical excision of the lump along with its capsule prevent its recurrence, with minimal blood loss [5].

Clinical demonstration of cellular angiofibroma may simulate many benign tumors like leiomyoma, angiomyofibroblastoma, spindle cell lymphoma and perineurioma [1, 11] for there are many common features between these tumors, but cellular angiofibroma differentiated with others by distinguishing feature of bland spindle cells and prominent hyalinized blood vessels in biopsy $[1,10,11]$.
Moreover, immunohistochemistry plays a substantial role in differentiating from these tumors as Cellular angiofibromas are consistently positive for vimentin with variable expression of CD34 and desmin, and negative for smooth muscle actin (SM A) and S-100 [10, 12].

Our case was a well-defined swelling in right groin region that simulated all above mentioned benign tumour along with inguinal and femoral hernia. These were ruled out on the basis of clinical findings and radiological investigations. Lesion was managed by complete excision and follow up. Final diagnosis of cellular angiofibroma was confirmed on the basis of histopathological findings.

\section{CONCLUSION}

Angiofibroma as a differential diagnosis of inguinal swelling is rare finding compared to the more prevalent conditions as hernias or lymph node masses. However a watchful examination with adequate use of radiological and pathological investigations is recommended.

\section{REFERENCES}

[1]. Nucci MR, Granter SR, Fletcher CDM. Cellular angiofibroma: a benign neoplasm distinct from angiomyofibroblastoma and spindle cell lipoma. Am J Surg Pathol. 1997;21:636-44.

[2]. Laskin WB, Fetsch JF, Mostofi FK. Angiomyofibroblastoma-like tumor of the male genital tract. Analysis of 11 cases with comparison to female angiomyofibroblastoma and spindle cell lipoma. Am J Surg Pathol. 1998;22:6-16.

[3]. Fletcher CDM, Unni KK, Mertens F. World Health Organization Classification of tumours: pathology and genetics of tumours of soft tissue and bone. Lyon: IARC; 2002.

[4]. Chen E, Fletcher CDM. Cellular angiofibroma with Atypia or Sarcomatous transformation: clinicopathologic analysis of 13 cases. Am J Surg Pathol. 2010;34:707-14.

[5]. Dikmen Y, Yucebilgin MS, Kazandi M, Zekioglu O, Akalin T, Ozdemir N. Cellular angiofibroma of the vulva: report of a case. Eur J Gynaecol Oncol. 2004;25(2):242-4.

[6]. Dufau JP, Soulard R, Gros P. Cellular angiofibroma, angiomyofibroblastoma and aggressive angiomyxoma: members of a spectrum of genital stromal tumours? Ann Pathol. 2002 Jun;22(3):2413.

[7]. Colombat M, Liard-M eillon ME, De Saint-Maur P, Sevestre H, Gontier M F. Cellular angiofibroma. A rare vulvar tumor. Report of a case. Ann Pathol. $200 \mathrm{Apr} ; 21(2): 145-8$. 
[8]. M icheletti AM, Silva AC, Nascimento AG, Da Silva CS, M urta EF, Adad SJ. Cellular angiofibroma of the vulva: case report with clinicopathological and immunohistochemistry study. Sao Paulo Med J. 2005 Sep;123(5): 250-2.

[9]. Chen E, Fletcher CD. Cellular angiofibroma with atypia or sarcomatous transformation: clinicopathologic analysis of 13 cases. Am J Surg Pathol. 2010 May;34(5):707-14.

[10]. Flucke U, van Krieken JH, Mentzel T. Cellular angiofibroma: analysis of 25 cases emphasizing its relationship to spindle cell lipoma and mammary-type myofibroblastoma. Mod Pathol. 2011;24(1):82-9.
[11]. Nucci MR, Fletcher CD. Vulvovaginal soft tissue tumours: update and review. Histopathology. 2000; 36(2):97-108.

[12]. M cCluggage WG, Perenyei M , Irwin ST. Recurrent cellular angiofibroma of the vulva. J Clin Pathol. 2002;55(6):477-9.

How to cite this article:

Devendra K. Prajapati, Kapil Rampal, Jyoti M Prajapati. A Large Inguinal Angiofibroma: A Rare Entity. Int J Intg M ed Sci 2016;3(7):328-331. DOI: 10.16965/ijims.2016.128 